\title{
Professor Nara Vaeusorn: the Asia Pacific Society of Cardiovascular Interventional Radiology (APSCVIR) gold medal award recipient for 2018
}

Wiwatana Tanomkiat, MD-Editor

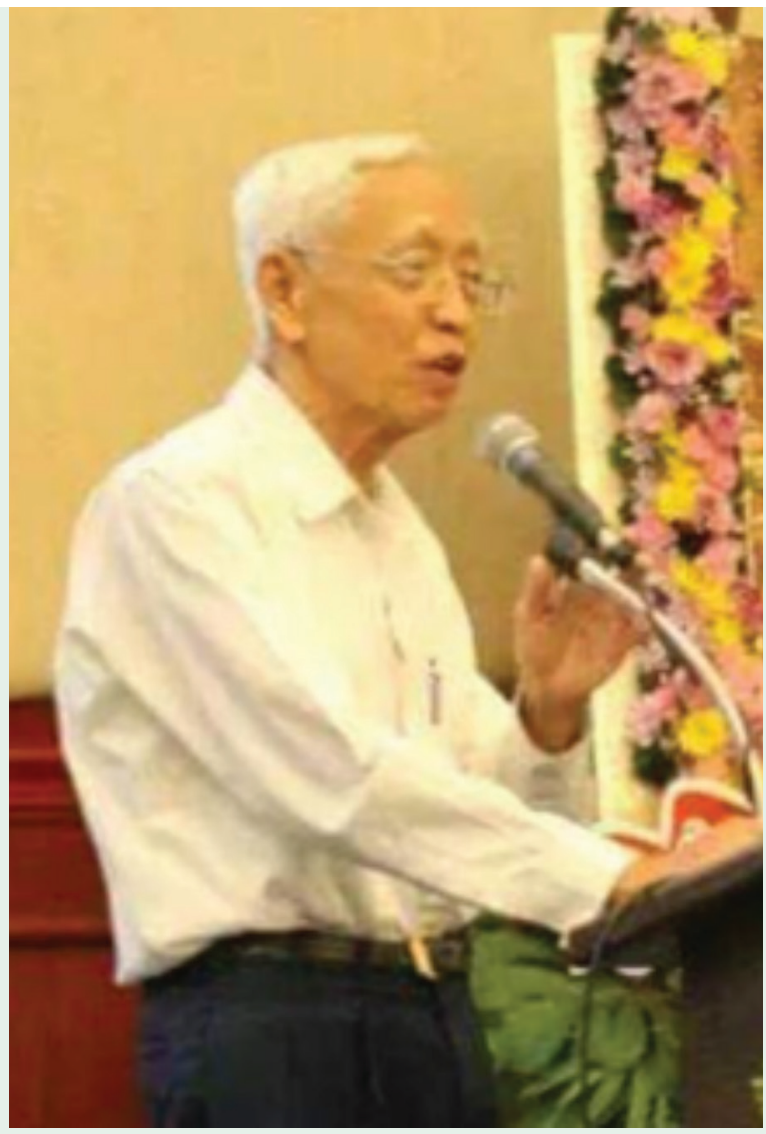

It was such a memorable moment to have a 2-hour talk with Professor Nara Vaeusorn at the west bank of the Chao Phraya River in Bangkok, the number 1 destination of tourists worldwide, in the vicinity of Siriraj Hospital, the largest hospital in Southeast Asia, where he started his legacy as the first radiological interventionist of Thailand in 1979. Initially aimed to be a radiotherapist but was later advised to be a diagnostic radiologist, Professor Nara Vaeusorn, born in 1934, found his great interest in angiology in his last year of residency at John Hopkins Medicine, 12 years after Dr. Seldinger's technique had opened the new era of angiology and, later on, radiological intervention in 1953 [1]. After having been working in angiology with Professor Rojana Suvanasuthi who first described and introduced Seldinger's

Figure 1: Professor Nara Vaeusorn, as one of the founders, gives a closing remark in the scientific meeting of the Thai Society of Vascular and Interventional Radiology (TSVIR) in October 2014 in Songkla, Thailand. 
technique in Thailand in 1959 [2] (but it was Dr. Sillawat Arthachinta who literally put this technique into practice for the first time in Thailand in 1963 [3]), he introduced the first successfully performed interventional procedure in Thailand which was embolization of an arteriovenous malformation at the left shoulder in a young female. The nationwide respect and recognition that interventional radiology obtained as a highly-effective, minimally-invasive treatment of bleeding in patients from obstetric-gynecologic, surgery and internal medicine departments in Siriraj Hospital are attributable to not only the success of this novel kind of treatment, but also his outstanding personality, his effective team, his impeccable system and trust-building among physicians.

When asked to describe the situation of angiology in the beginning phase, he referred to Professor Saman Mantaporn (1914-2001), the famous cardiovascular surgeon, as the first person who performed angiography in Thailand in 1952 [4]. In terms of the aortic angiography, Professor Tawan Surawongse Bunnag reported a peculiar aortic disease, later known as Takayasu disease, by performing translumbar aortograms [5]. Angiography most frequently performed during his time was occlusive arterial disease in laborers, often trishaw drivers and ferry boat paddlers, who were malnourished and heavily smoking, presented with gangrenous digits [6]. He also reported the first case of angiographic findings of aortic dissection in Thailand [7]. The procedure and findings were far much more complicated than CT which now takes a few minutes to clearly demonstrate true and false lumens. Better and faster image technologies will likely replace the old ones, I assumed, but very few younger radiologists can reach his standard. I was advised a few words I have to apologize you for not being able to put them. We quickly separated in order to avoid the famous Bangkok's crazy Friday-evening rush hour traffic. I will highly likely meet him more often as the Radiological Society of Thailand (RST) and the Royal College of Radiologists of Thailand (RCRT) are going to celebrate the 90th academic year of Radiology in Thailand in 2018, and to do so without him is certainly impossible.

A few days after our encounter, I was delighted but not surprised to learn that he was one of the 2 Asia Pacific Society of Cardiovascular Interventional Radiology (APSCVIR) gold medal award recipients for 2018 . 


\section{References}

1. Seldinger SI. Catheter replacement of the needle in percutaneous arteriography; a new technique. Acta radiol 1953;39:368-76.

2. Samerasuta A. ข้อสังเกตในการประชุม The Ninth International Congress of Radiology will be held in Munich, Germany, July 23 to July. 30, 1959. Siriraj Hosp Gaz 1959; 11:432-4.

3. Arthachinta S. การศึกษาหัวใจและเส้นโลหิต โดยวิธีแทงโดยตรงและสอดสายสวนเข้าในเส้นโลหิต ตามวิธีของ Seldinger : ความรู้บางประการจากการศึกษา 2 ปี ที่โรงพยาบาลจุฬาลงกรณ์. Thai J Radiol 1965; 3(2): 1-7.

4. Muntarbhon S. Traumatic artorial. J Med Assoc Thai 1951; 34(5-6): 11-24.

5. Bunnag T. Co-arctation ของ abdominal aorta ตรงจุดเริ่มต้นของ Interior mesenteric artery. Chula Med J 1957; 4:27-31.

6. Vaewsorn N, Tritrakan A, Vanapruks S, Prabhasawab D, Hargrove NS, Bhothisuwan W, et al. An analysis of cases of occlusive arterial disease studied in the Department of Radiology. Thai J Radiol 1982;19: 1-26.

7. Sirivit S, Vaeusorn N, Vanapruks S, Prabhasavat D. An analysis of cases of dissecting aneurysm of aorta at Siriraj Hospital during the year 1969-1978.Thai J Radiol 1980; 17(1): 60-6. 